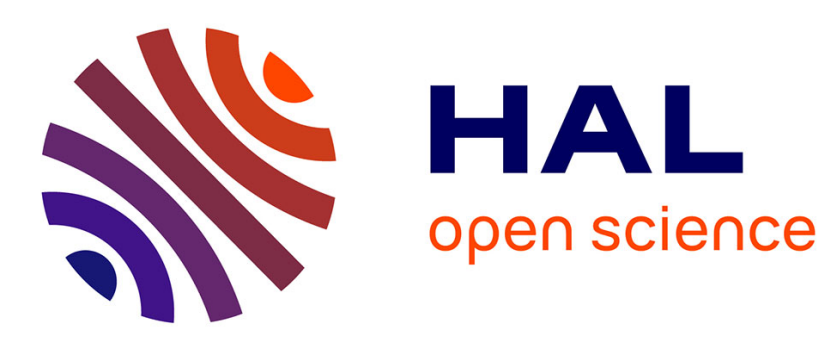

\title{
Acute anuria after a family vacation to Corsica/France
}

\author{
J. Richter, M.C. Holtfreter,, Gabriel Mouahid, Hélène Moné
}

\section{To cite this version:}

J. Richter, M.C. Holtfreter, Gabriel Mouahid, Hélène Moné. Acute anuria after a family vacation to Corsica/France. Parasitology Research, 2016, 115 (4), pp.1733-1735. 10.1007/s00436-016-4944-2 . hal-01311046

\section{HAL Id: hal-01311046 \\ https://hal-sde.archives-ouvertes.fr/hal-01311046}

Submitted on 29 Jan 2021

HAL is a multi-disciplinary open access archive for the deposit and dissemination of scientific research documents, whether they are published or not. The documents may come from teaching and research institutions in France or abroad, or from public or private research centers.
L'archive ouverte pluridisciplinaire HAL, est destinée au dépôt et à la diffusion de documents scientifiques de niveau recherche, publiés ou non, émanant des établissements d'enseignement et de recherche français ou étrangers, des laboratoires publics ou privés. 
Joachim RICHTER ${ }^{1}$, Martha HOLTFRETER ${ }^{1}$, Gabriel MOUAHID² \& Hélène MONE²

1- Tropical Medicine Unit, Department of Gastroenterology, Hepatology and Infectious Diseases, Heinrich-Heine-University Düsseldorf, Düsseldorf, Germany

2- Univ. Perpignan Via Domitia, IHPE UMR 5244, CNRS, IFREMER, Univ. Montpellier, 58 avenue Paul Alduy, Bât. R, F-66860 Perpignan, France

Corresponding author : Joachim.Richter@med.uni-duesseldorf.de

\begin{abstract}
A 12-year-old male patient suffered hematuria. Histopathology of a biopsy showed granulomata suspicious for schistosomiasis. The patient had never travelled outside Europe duringhisentirelifetime. Hehadtakenfrequentbathesinvarious rivers during his last family holidays 5 months earlier in Corsica. Microfiltration of urine revealed viable ova of Schistosoma haematobium with alterated size and shape. Ultrasonography showed a large focal echopoor mass attached to the bladder roof. Four days after antihelminthic therapy, the patient suffered inferior abdominal pain and acute anuria. Ultrasound revealed an approximately $5-\mathrm{cm}$ mass in the bladder lumen suspicious for a large blood clot. After taking non-invasive measures such as drinking high amounts of fluid and treating the lower abdomen with a warm water bag and massage, the clot was excreted with urine and symptoms subsided. The further course was uneventful until 11 months later when hematuria recurred. This time, parasitological urine examination confirmed non-viable schistosome ova. Hematuria was likely due to erosion of the bladder mucosa by calcified non-viable ova.
\end{abstract}

\title{
Keywords
}

Schistosoma haematobium. Schistosoma bovis . Urinary schistosomiasis. Hematuria . Acute anuria . Blood clot . Corsica . France . 2013 


\section{Case report}

A 12-year-old male patient noticed bloody urine. Therefore, he was referred to a urology department. Since no infectious agent could be detected, cystoscopy was performed where a severe cystitis was detected. Histology of a bladder wall biopsy showed a granulomatous inflammation and schistosomiasis was suspected. Because of the suspected tropical origin of the disease the adolescent was referred to our Tropical Medicine Unit. Detailed history was again taken which confirmed that he had never travelled outside Europe during his entire lifetime. The travels which had headed most south were to Spain, where no exposure to freshwater had taken place and Southern France including South Eastern Corsica, where the patient had spent his last summer holidays 5 months earlier together with his family and taken frequent bathes in various rivers.

At presentation in our unit, the patient had a normal leukocyte count with a relative blood eosinophilia of

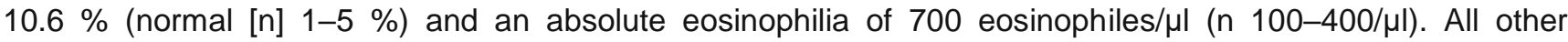
hematology and biochemistry results including $\mathrm{IgE}$ were normal. Urin dipstick revealed erythrocyturia (250 erythrocytes/ $\mu \mathrm{l})$ and leukocyturia $(25 / \mu \mathrm{l})$ with a normal $\mathrm{pH}(5)$ and negative nitrite.

Microfiltration of urine collected from 11.00 am until $1.00 \mathrm{pm}$ of the following day revealed viable ova of Schistosoma haematobium with a slightly decreased size and alterated shape. In parasitological stool examinations, no ova were detected. Serology revealed antibodies against schistosomal cercariae and adult schistosomes.

Ultrasonography showed generalized thickening of the bladder wall in a bladder insufficiently filled because the boy had difficulties to withhold the urine with a large focal echopoor mass attached to the bladder roof (Fig. 1). Besides, a moderate splenomegaly with an increased acoustic radiation force impulse (ARFI) of $2.62 \mathrm{~m} / \mathrm{s}$ no other sonographic abnormality was detected. The boy was treated with praziquantel at a single standard dose of $40 \mathrm{mg} / \mathrm{kg}$ body weight (AWMF 2013). Four days later, the patient suffered acute lower abdominal pain and anuria. Ultrasound revealed an approximately $5-\mathrm{cm}$ mass in the bladder lumen suggesting a large blood clot (Fig. 2). Upper urinary tract obstruction was excluded sonographically. Since the boy was afraid of another bladder catheterism, non-invasive measures were attempted by advising the patient to drink high amounts of fluid and to treat the lower abdomen with a hot water bag and massage.

Thereby, he succeeded in mobilizing the clot and excreting it with urine (Fig. 3). Ultrasound performed on the following day confirmed that the blood clot had been successfully excreted; the bladder lumen was free. To reduce the risk of sequelae, the patient was retreated 3 months later. The further course was uneventful until 11 months later when hematuria recurred after soccer training. This time, parasitological urine examination confirmed schistosome ova which by morphology were no more viable. Hematuria in this circumstance was most likely due to erosion of the bladder mucosa by calcified non-viable ova and did not indicate a persistent infection a finding supported by a normalized eosinophil count, decreasing titers in anti-schistosome-antibodies and normal ultrasound findings of the urinary tract.

\section{Discussion}

Schistosomiasis is a helminthic infection involving 240 to 400 million people worldwide. It is endemic in Africa, the Arabian peninsula, South America, and East and South-East Asia (WHO 2012; Colley et al. 2014). Intestinal schistosomiasis is caused by Schistosoma (S.) mansoni, S. japonicum, S. intercalatum, S. guineensis, and S. mekongi. However, the most prevalent species is $S$. haematobium, causing urinary and genital schistosomiasis. Human and zoonotic schistosomiasis had been endemic until 55 years ago in the extreme South of Europe including Portugal and Greece (Davies 2009).

This was the first autochthonous case of schistosomiasis acquired in Europe published since its eradication in the 1960s of the last century and the first human case ever reported from Corsica (Holtfreter et al. 2014). The alert via the surveillance networks soon was followed by reports of other cases occurring in European travelers (Berry et al. 2014; Patard et al. 2015; Brunet et al. 2015)

Our patient's father also excreted schistosome ova whereas his siblings, who had been exposed in the same rivers had a positive schistosomiasis serology only, but did not excrete ova. Schistosomiasis had never been described to be endemic in Corsica before. However, at least one of the vector snails of $S$. haematobium, i.e., Bulinus (B.) truncatus, was known to be endemic in some areas of South Europe including Corsica, a notion which was confirmed recently (Berry et al. 2014). Most likely, local B. truncatus snails have been infected by miracidia from urines excreted by African immigrants or travelers originating from endemic areas to Corsica and a transmission cycle has been established during the hot summer months also involving local zoonotic S. bovis 
strains (Moné et al. 2015). In such a circumstance, schistosomiasis may affect individuals who have never travelled to known endemic areas.

Usually, even severe abnormalities of the bladder wall due to schistosomiasis are astonishingly well reversible after therapy (Richter 2000; Akpata et al. 2015). In the present case, a bladder mass was formed by coagulated blood which once detached from the bladder roof fell into the lumen and obstructed the urethra causing acute anuria. After excretion of the blood clot the bladder mass initially seen had also disappeared. To our knowledge in schistosomiasis, acute anuria due to an obstructing blot clot in the urinary bladder has so far not been described in the literature. The hematuria recurrency illustrates that sequelae of schistosomiasis may occur months to years after successful treatment and cause confusion. This shows that even without any reexposure a year after successful treatment, hematuria may recur which does not necessarily indicate the evolution of praziquantel resistant parasites. This has also importance in the context of schistosomiasis control in endemic areas (Cioli et al. 2014).

The acute anuria due to the obstruction of the urethra adds to other unusual presentations of schistosomiasis including vesicovaginal fistulae, hydrocele, or placental involvement (Richter et al. 2002a, b, 2008; Schleenvoigt et al. 2014). The case also illustrates the possible expansion of autochthonous transmission to formerly non-endemic areas. It confirms the potential transmission of "exotic" infections among these malaria, leishmaniasis, dengue fever, chikungunya, amoebiasis, rickettsial infections, cutaneous larva migrans, or cystic echinococcosis to people who have never left Europe or have acquired their infection in Germany (Krüger et al. 2001; Bogdan Schönian et al. 2001; Richter et al. 2002b, 2006, 2009)

\section{Compliance with ethical standards}

\section{Conflict of interest}

The authors declare that they have no conflicts of interest. 


\section{References}

Akpata R, Neumayr A, Holtfreter MC, Krantz I, Singh DD, Mota R, Hatz C, Richter J (2015) The WHOultrasonography protocol for assessing morbidity due to Schistosoma haematobium. Acceptance and evolution over 14 years. Systematic review. Parasitol Res 114: 1279-1289

Arbeitsgemeinschaft Wissenschaftlicher Medizinischer Fachgesellschaften (AWMF) guideline diagnostics and therapy of schistosomiasis (Leitlinie: Diagnostik und Therapie der Schistosomiasis [Bilharziose]) AWMFRegister Nr. 042/005 2013: 1- 36

Berry A, Moné H, Iriart X, Mouahid G, Aboo O, Boissier J, Fillaux J, Cassaing S, Debuisson C, Valentin A, Mitta G, Théron A, Magnaval JF (2014) Schistosomiasis haematobium, Corsica, France. Emerg Infect Dis 20(9):1595-1597

Bogdan Schönian G, Bañuls AL, Hide M, Pratlong F, Lorenz E, Röllinghoff M, Mertens R (2001) Visceral leishmaniasis in a German child who had never entered a known endemic area: a case report and review of the literature. Clin Infect Dis 32:302-306

Brunet J, Pfaff AW, Hansmann Y, Gregorowicz G, Pesson B, Abou-Bacar A, Candolfi E (2015) An unusual case of hematuria in a French family returning from Corsica. Int $\mathrm{J}$ Infect Dis 31:59-60. doi:10. 1016/j.jijid.2014.10.024

Cioli D, Pica-Mattoccia L, Basso A, Guidi A (2014) Schistosomiasis control: praziquantel forever? Mol Biochem Parasitol 195(1):23-29

Colley DG, Bustinduy AL, Secor WE, King CH (2014) Human schistosomiasis. Lancet 383:2253-2264. doi:10.1016/S0140-6736(13) 61949-2

Davis A (2009) Schistosomiasis. In: Cook GC, Zumla Al (eds) Manson's tropical diseases, 22nd edn. Saunders, Elsevier, Edinburgh, pp 1425-1460

Holtfreter MC, Moné H, Müller-Stöver I, Mouahid G, Richter J (2014) Schistosoma haematobium infections acquired in Corsica, France, August 2013. Euro Surveill;19(22). pii: 20821

Krüger A, Rech A, Su XZ, Tannich E (2001) Two cases of autochthonous P. falciparum malaria in Germany with evidence for local transmission by indegenous Anopheles plumbeus. Trop Med Int Hlth 6:983-985

Moné H, Holtfreter MC, Allienne JF, Mintsa-Nguéma R, Ibikounlé M, Boissier J, Berry A, Mitta G, Richter J, Mouahid G (2015) Introgressive hybridizations of Schistosoma haematobium by Schistosoma bovis at the origin of the first case report of schistosomiasis in Corsica (France, Europe). Parasitol Res. [Epub ahead of print]

Patard PM, Debuisson C, Mouttalib S, Berry A, Garnier A, Galinier P, Abbo O (2015) Urinary schistosomiasis contracted in a child in Corsica. Arch Pediatr 22(3):327-8

Richter J (2000) Evolution of schistosomiasis-induced pathology after therapy and interruption of exposure to schistosomes: a review of ultrasonographic studies. Acta Trop 77:111-131

Richter J, Stegemann U, Häussinger D (2002a) Hydrocele in a young boy with Schistosoma mansoni infection. BJU Int 89(9cr):971-972

Richter J, Fournier PE, Petridou J, Häussinger D, Raoult D (2002b) A case of PCR-documented Rickettsia felis infection in Europe. Emerg Infect Dis 8(2):207-208

Richter J, Heintges T, Thomassen D, Tannich E, Häussinger D (2006) An unsuspected cause of chronic colitis. Gut; 55(6): 832; 841.

Richter J, Lux J, Reinecke P, Müller-Mattheis V (2008) Of flukes and fistulae. Lancet 371:1308

Richter J, Orhun A, Grüner B, Müller-Stöver I, Reuter S, Romig T, Häussinger D, Kern P (2009) Autochthonous cystic echinococcosis in patients who grew up in Germany. Eurosurveillance; 14 (22), epub 4.6.2009

Schleenvoigt BT, Gajda M, Baier M, Groten T, Oppel-Heuchel H, Grimm MO, Pfister W, Richter J, Pletz MW (2014) Placental Schistosoma haematobium infection in a German returnee from Malawi.

Infection 42(6):1061-4

World Health Organization (2012) WHO. Schistosomiasis. Progress Report 2001-2011 and Strategic Plan 2012-2020. WHO Geneva 2012 http://www.who.int last accessed, Dec 2, 2015. 


\section{Figure 1}

Ultrasound mass attached to the urinary bladder roof and generally thickened bladder wall (during examination, the patient had difficulties to hold his urine)

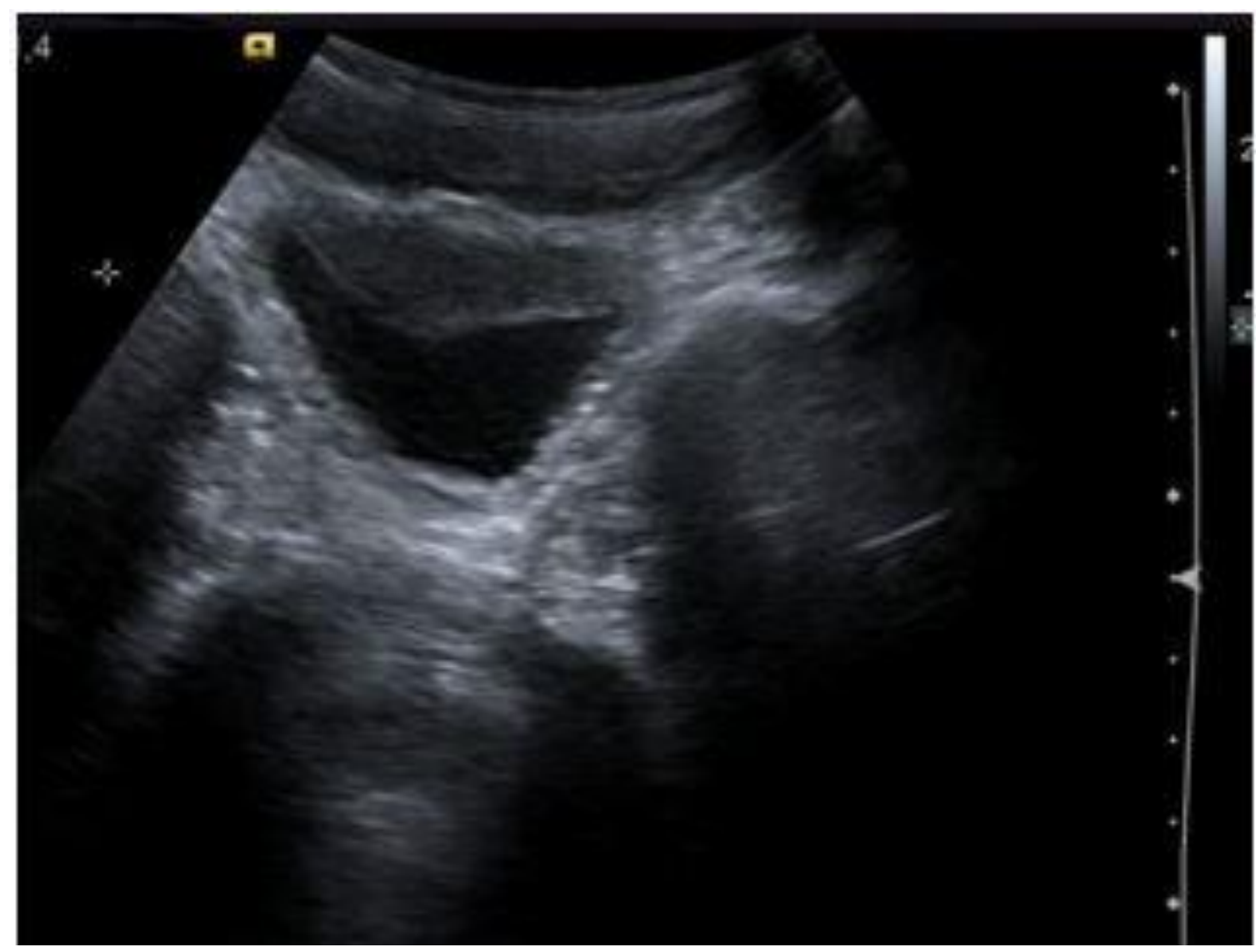


Figure 2

Blood clot inside the bladder lumen

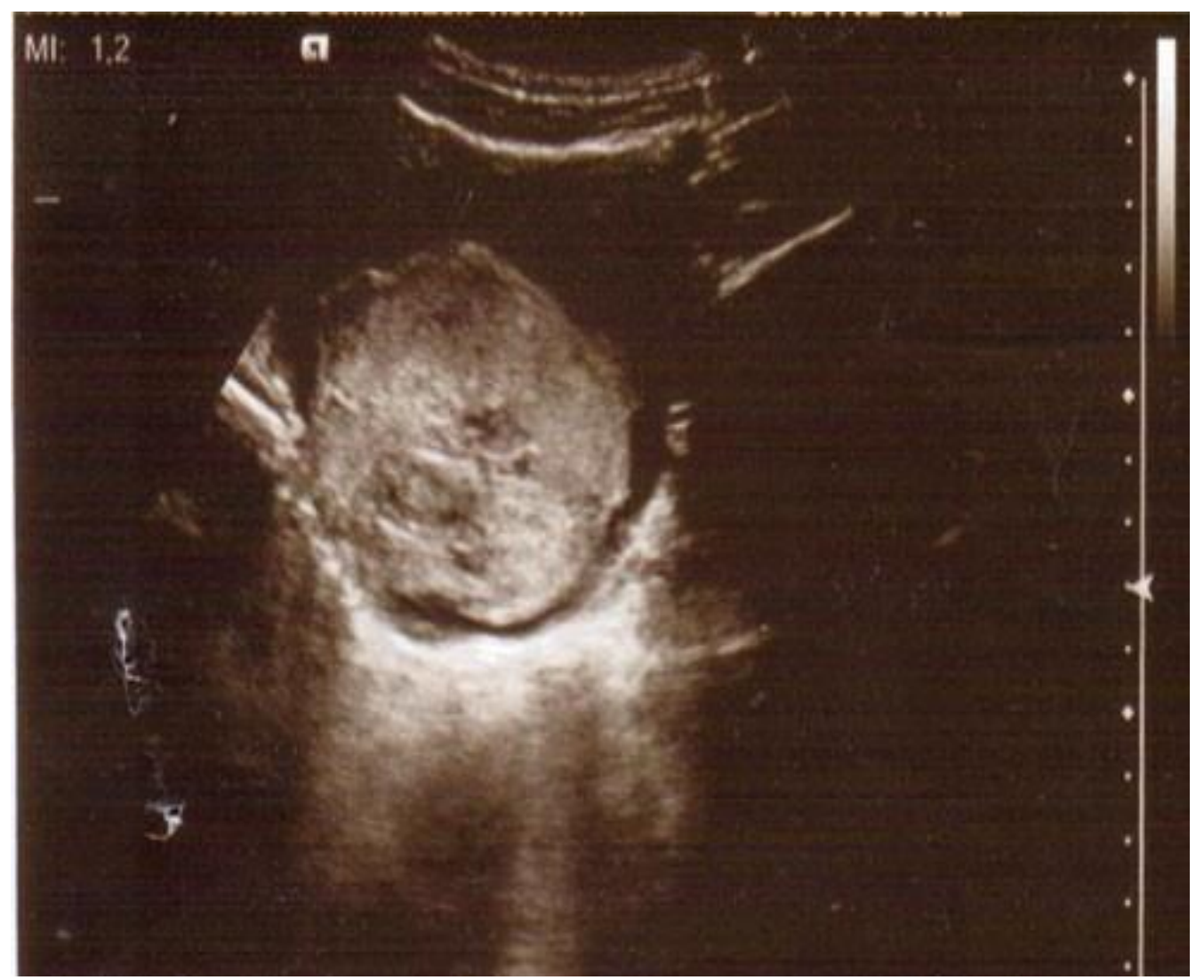


Figure 3

Macrohematuria and coagulated blood excreted with urine

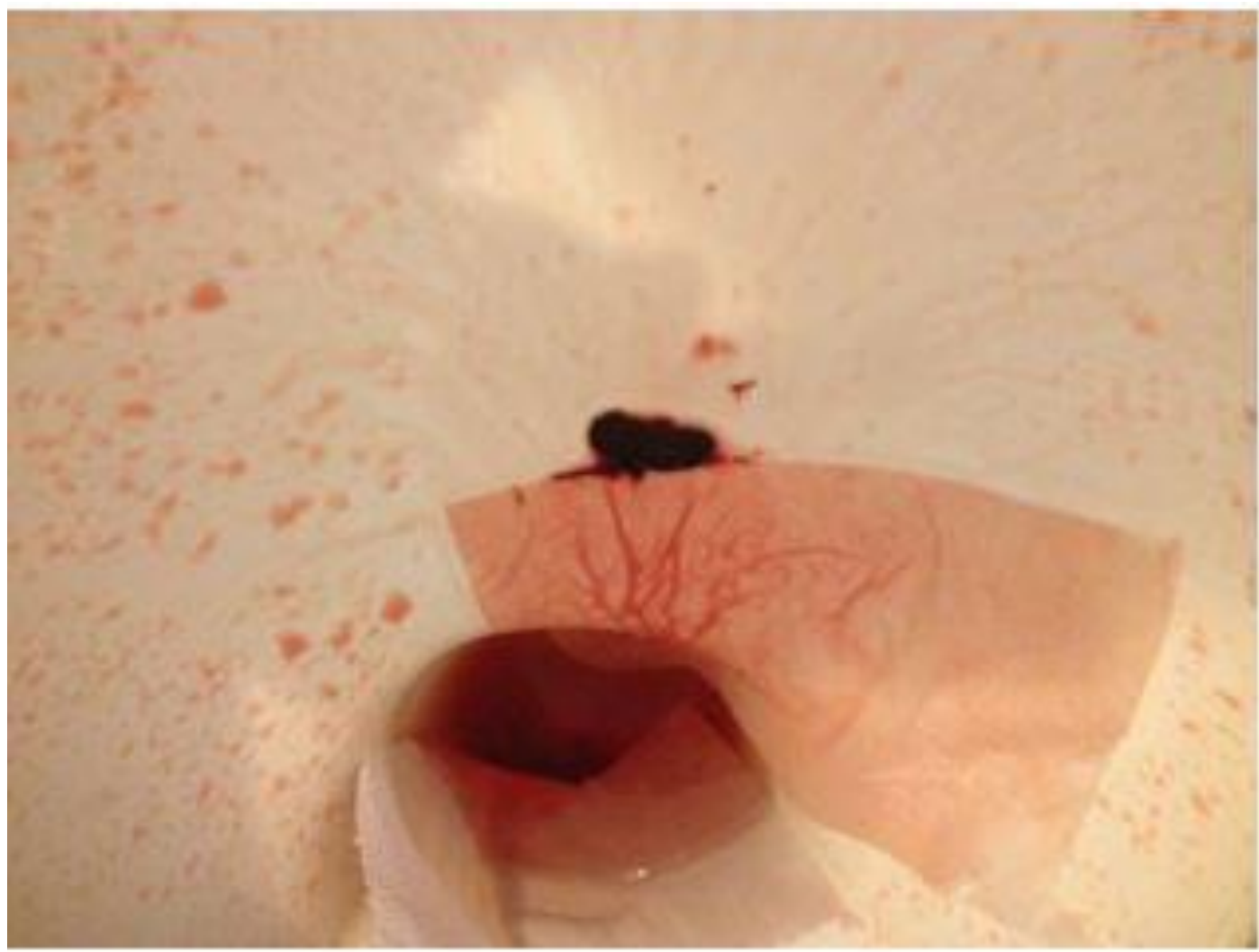

